\title{
IMPLEMENTASI PENJAMINAN MUTU DALAM MENGHADAPI GLOBALISASI, ANALISIS DAN IMPLIKASI:STUDI KASUS
}

\author{
Rorim Panday \\ Universitas Pakuan, Bogor, Indonesia \\ Email: indripan@yahoo.co.id
}

\begin{abstract}
ABSTRAK
Globalisasi mengharuskan kualitas yang tinggi yang diharapkan oleh para pelanggan, karena itu merupakan tolok ukur dalam mempertahankan kesetiaan pelanggan. Disisi lain untuk mempertahankan hidupnya suatu organisasi atau perusahaan, baik oganisasi profit dan non profit dalam lingkungan industri produk dan industri jasa. Untuk menjaga kualitas tersebut dibutuhkan penjaminan mutu yang konsisten integritasnya dan dilaksanakan secara periodik, tidak terkecuali institusi pendidikan. Program studi merupakan satu bagian program pendidikan dari beberapa program yang ada di institusi Perguruan tinggi. Keberadaan program studi merupakan ujung tombak dari sistem produksi di perguruan tinggi. Oleh sebab itu pengelolaan program studi yang bermutu harus dilaksanakan dengan baik sesuai dengan kebutuhan pasar dan peraturan yang telah ditetapkan oleh regulator. Semakin tinggi mutu yang dicapai oleh program studi, semakin tinggi pula penilaian dari regulator yang dikenal dengan akreditasi. Pelaksanaan program studi di Indonesia harus mengacu pada Standar Nasional Pendidikan Tinggi (SNPT) yang dikeluarkan oleh Kementerian Pendidikan dan kebudayaan. SNPT ini dibuat untuk menjamin pelaksanaan pendidikan di program studi telah memenuhi standar yang disyaratkan, yang pada akhirnya menghasilkan lulusan yang bermutu. Untuk memudahkan dalam mengevaluasi pelaksanaan program studi, maka dibuatlah instrumen Evaluasi Mutu Internal (EMI) yang mengacu pada SNPT. Di dalam EMI, standar pendidikan tersebut dibuat menjadi 11 standar yaitu: standar isi, standar proses, standar kompetensi lulusan, standar pendidikan dan tenaga kependidikan, Standar sarana dan prasarana, standar pengelolaan, standar pembiayaan, standar penilaian, standar penelitian, standar pengabdian pada masyarakat dan standar kerjasama. Penilaian standar tersebut mengggunakan skala yang diadopsi dari Asian Network University (AUN) yaitu skala 1 sampai 7. Pelaksanaan EMI dilakukan oleh penyelenggara pendidikan tinggi secara mandiri. Penelitian ini adalah penelitian kualitatif dilakukan dengan cara Focus Group Discussion (FGD). Temuan hasil Evaluasi Mutu Internal menunjukkan bahwa di dalam pelaksanaan program studi masih terdapat beberapa kekurangan yaitu pada standar pembiayaan, standar penelitian, standar pengabdian pada masyarakat dan standar kerja sama. Untuk selanjutnya, hasil dari EMI ini dapat digunakan sebagai acuan untuk perencanaan pengembangan mutu pendidikan dari program studi untuk satu tahun ke depan guna menuju pada tingkat akreditasi yang direncanakan.

Kata kunci: Implementasi, penjaminan mutu, standar
\end{abstract}




\begin{abstract}
Globalization requires high quality expected by customers, because it is a benchmark in maintaining customer loyalties. On the other hand, in keeping the life of an organization or company, both profit organizations and non-profit organizations event in the environment industrial products and also services industries. In maintaining the quality assurance requirements shall consistent to implement the integrity periodically, educational institutions are no exception. The program of study is a part of the educational program for several existing programs in a college institution. The existence of the study program is the spearhead of the production system in college. Therefore, quality management of study program should be conducted properly in accordance with market requirements and rules set by the regulator. The achievement of higher quality by a program of study, the higher rate of assessment giving by regulators known as accreditation. Implementation of the program of study in Indonesia should refer to the National Standards for Higher Education (SNPT) issued by the Ministry of Education and Culture. SNPT is made to ensure the implementation of education towards program study that already meet the required standards, in order to produce quality graduates. To make it easier in implementing evaluation of the program of study, the instrument was made of Internal Quality Evaluation (EMI) which refers to SNPT. In the EMI, the educational standards are made in 11 standards, namely: content standards, process standards, competency standards, educational standards and educational human resources, facilities and infrastructure standards, management standards, financial standards, assessment standards, standards of research, community service standards and partnership standards. The standard assessment scales are adopted from Asian University Network (AUN) is scaling from 1 unto 7. Implementation of EMI is conducted by higher education provider independently. This study is doing in qualitative research which conducted by Focus Group Discussion (FGD). The findings of Internal Quality Evaluation indicate that in the implementation of program of study in the institution are still some lacks from the requirement, namely for the funding standards, research, community service standards and partnership standards. Henceforth, the results of EMI can be used as a reference for planning development of quality education study program for the coming year in order to lead to the planned level of accreditation.
\end{abstract}

Key words: Implentation, quality assurance, standards.

\title{
PENDAHULUAN
}

Globalisasi mengharuskan kualitas yang tinggi yang diharapkan oleh para pelanggan, karena itu merupakan tolok ukur dalam mempertahankan kesetiaan pelanggan. Disisi lain untuk mempertahankan hidupnya suatu organisasi atau perusahaan, baik oganisasi profit dan non profit dalam lingkungan industri produk dan industri jasa. Untuk menjaga kualitas tersebut dibutuhkan penjaminan mutu yang konsisten integritasnya dan dilaksanakan secara periodik, tidak terkecuali institusi pendidikan. Persaingan di dalam industri pendidikan sudah terjadi di seluruh dunia, 
sudah mengglobal. Dunia pendidikan sudah merupakan bagian dari pelayanan jasa, dalam hal jasa pendidikan, untuk menjadikan seseorang pintar, ahli, kompeten, inovatif, kreativ dan sebagainya. Perbagai model dan moda pendidikan ditawarkan, baik di dalam negeri maupun di luar negeri. Semuanya itu terjadi juga sebagai akibat dari tuntutan kebutuhan akan tenaga kerja. Kualifikasi tenaga kerja yang kompeten juga semakin meningkat kebutuhannya. Oleh karena itu setiap perguruan tinggi berusaha untuk dapat melayani permintaan dunia industri pemakai lulusan dari perguruan tinggi. Untuk itu pula pemerintah Indonesia, juga membuat aturan agar perguruan tinggi di Indonesia menjadi perguruan tinggi yang mutunya dapat dihandalkan, bahkan dapat bersaing dengan perguruan tinggi dari luar negeri.

\section{Evaluasi Mutu Internal (EMI)}

Untuk menjamin mutu pendidikan, sebagaimana diamanatkan dalam Pasal 50 ayat (6) UU Nomor 20 Tahun 2003 tentang Sisdiknas juncto Pasal 91 PP No. 19 Tahun 2005 tentang Standar Nasional Pendidikan, kegiatan sistemik penjaminan mutu penyelenggaraan pendidikan tinggi di perguruan tinggi oleh perguruan tinggi (internally driven), untuk mengawasi penyelenggaraan pendidikan tinggi oleh perguruan tinggi sendiri secara berkelanjutan (continuous improvement ) perlu dilakukan. Sesuai dengan Permendinas Nomor 36 Tahun 2010 Pasal 717, maka Pusat Penjaminan Mutu Pendidikan mempunyai tugas melaksanakan penyusunan bahan kebijakan teknis dan penjaminan mutu pendidikan. Pusat Penjaminan Mutu telah membuat instrumen yang dapat digunakan oleh perguruan tinggi dalam melakukan evaluasi mutu internalnya, yang disebut dengan instrumen Evaluasi Mutu Internal (EMI).

Substansi Alat Evaluasi Mutu Internal Perguruan Tinggi disusun dengan mengacu pada 8 Standar Nasional Pendidikan, sesuai dengan PP No. 19 Tahun 2005 tentang Standar Nasional Pendidikan (SNP), ditambah dengan Standar Penelitian, Standar Pengabdian kepada Masyarakat, dan Standar Kerjasama. Substansi Alat Evaluasi Mutu Internal Perguruan Tinggi (EMI PT) juga disusun dengan mengacu pada Instrumen Akreditasi Perguruan Tinggi yang ditetapkan oleh Badan Akreditasi Nasional Perguruan Tinggi (BAN-PT) yang menetapkan kelayakan program dan/atau satuan pendidikan pada jenjang pendidikan tinggi dengan mengacu pada 
Standar Nasional Pendidikan (Pasal 1 Butir 27 PP No. 19 Tahun 2005 tentang Standar Nasional Pendidikan). Tujuan EMI-PT ini untuk (1) membantu perguruan tinggi dan pemerintah menetapkan program pengembangan menuju pemenuhan SNP, dan (2) menghindari terjadinya kesenjangan antara hasil evaluasi internal dengan eksternal. Selain mengacu pada Instrumen Akreditasi Perguruan Tinggi, Alat Evaluasi Mutu Internal Perguruan Tinggi juga ditetapkan berdasarkan: (1) berbagai standar yang berlaku di dunia internasional (AUN, Webometric) untuk membantu pemerintah dan perguruan tinggi mengembangkan pendidikan yang berkualitas dan mampu bersaing di kancah regional dan internasional, (2) keberagaman potensi dan sumber daya Perguruan Tinggi di Indonesia, serta (3) contoh praktek baik yang ada di Indonesia.

Di samping hal-hal pokok yang dikemukakan sebelumnya, EMI PT dikembangkan untuk memfasilitasi pemetaan mutu perguruan tinggi, memfasilitasi resource sharing dan partnership antar-PT maupun dengan institusi lainnya (pemerintah, industri, dan masyarakat), serta memudahkan mekanisme umpan balik yang bersifat pembinaan dan pengembangan oleh pemerintah.

EMI PT merupakan instrumen evaluasi diri yang akan ditinjau secara berkala, disesuaikan dengan kondisi-kondisi internal Perguruan Tinggi, praktek baik yang berlaku di Indonesia, tuntutan nasional, serta perkembangan di dunia internasional, dengan membuka peluang pengembangan sesuai dengan alternatif model-model evaluasi yang terus berkembang secara dinamis.

Pelaksanaan EMI di UPT diawali dengan membentuk Tim Penjaminan Mutu PT (TPM-PT). Kemudian TPM-PT melaksanakan EMI dengan mengisi instrumen EMI yang disertai bukti fisik pendukungnya yang penilaiannya dalam bentuk Focus Group Discussion (FGD). Selanjutnya TPM-PT melakukan analisis hasil EMI sampai menyusun laporan EMI.EMI dilaksanakan sekurang-kurangnya setahun sekali dan hasilnya digunakan sebagai dasar bagi perencanaan kegiatan dan pengembangan kapasitas PT menuju tercapainya atau terlampauinya 11 SNP-PT. Gambar-1 menunjukkan mekanisme siklus kerja EMI. Dan Tabel-1 menunjukkan 11 standar yang dipakai dan banyaknya indikator pada setiap standar. 


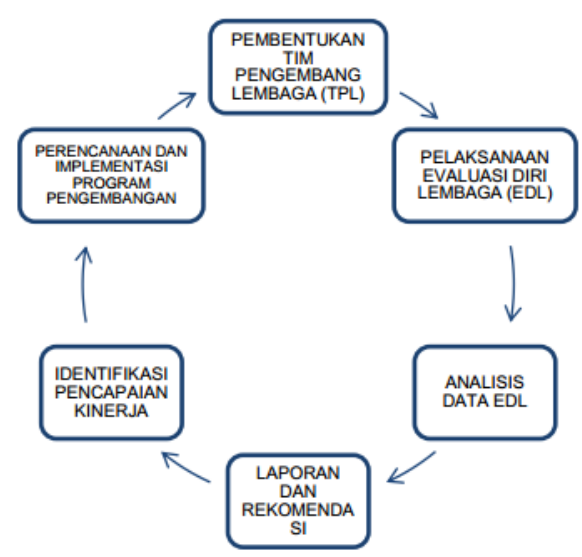

Gambar 1. Pelaksanaan EMI PT

Tabel 1. Standar dalam EMI PT dan jumlah indikator

\begin{tabular}{|l|l|r|}
\hline A & Standar Isi & 5 \\
\hline B & Standar Proses & 10 \\
\hline C & Standar Kompetensi Lulusan & 10 \\
\hline D & Standar Pendidik dan Tenaga Kependidikan & 4 \\
\hline E & Standar Sarana dan Prasarana & 8 \\
\hline F & Standar Pengelolaan & 20 \\
\hline G & Standar Pembiayaan & 9 \\
\hline H & H Standar Penilaian & 6 \\
\hline I & Standar Penelitian & 12 \\
\hline J & Standar Pengabdian kepada Masyarakat & 6 \\
\hline K & Standar Kerjasama & 7 \\
\hline & Jumlah & 97 \\
\hline
\end{tabular}

Seluruh indikator yang tertera pada Instrumen EMI PT berisikan pertanyaan atau pernyataan yang tertutup yang jawabannya diekuivalensikan dengan skor 1 sampai 7 , mengacu pada rubrik setiap skor. Skor 1 sampai 7 mengacu pada dasar pentahapan pada setiap indikator sebagai berikut:

1= Sama sekali tidak mencukupi , perbaikan harus segera dilakukan (absolutely inadequate; immediate improvements must be made)

$2=$ Tidak mencukupi , perlu perbaikan besar ( inadequate, improvements necessary) 3=Kurang mencukupi, perbaikan minor akan menjadikan butir kualitas ini mencukupi ( inadequate, but minor improvements will make it adequate)

4= Mencukupi sesuai yang diharapkan (adequate as expected)

$5=$ Lebih dari mencukupi (better than adequate)

$6=$ Merupakan contoh pelaksanaan yang baik (example of good practice)

$7=$ Sangat baik (excellent) 
Bukti fisik yang ada disesuaikan dengan rubrik yang tersedia. Selanjutnya hasil akhir penilaian dengan skala 7 dikonversi kedalam skala 100, dan dihitung nilai rata-rata kualitas. EMI ini dapat digunakan untuk mengevaluasi Prodi dan Perguruan Tinggi.

\section{Evalusi Mutu Internal Prodi}

Program studi merupakan satu bagian program pendidikan dari beberapa program yang ada di institusi Perguruan tinggi. Keberadaan program studi merupakan ujung tombak dari sistem produksi di perguruan tinggi. Oleh sebab itu pengelolaan program studi yang bermutu harus dilaksanakan dengan baik sesuai dengan kebutuhan pasar dan peraturan yang telah ditetapkan oleh regulator. Semakin tinggi mutu yang dicapai oleh program studi, semakin tinggi pula penilaian dari regulator yang dikenal dengan akreditasi. Pelaksanaan program studi di Indonesia harus mengacu pada Standar Nasional Pendidikan Tinggi (SNPT) yang dikeluarkan oleh Kementerian Pendidikan dan kebudayaan. SNPT ini dibuat untuk menjamin pelaksanaan pendidikan di program studi telah memenuhi standar yang disyaratkan, yang pada akhirnya menghasilkan lulusan yang bermutu.

\section{LANDASAN TEORI}

Untuk memastikan bahwa Universitas memenuhi persyaratan mutu, sejumlah prosedur jaminan kualitas beroperasi. Beberapa di antaranya dijalankan oleh Universitas itu sendiri, sedangkan yang lain melibatkan pengawasan eksternal. Kedua prosedur internal dan eksternal beroperasi sesuai dengan pedoman di Indonesia. Jaminan kualitas merupakan proses untuk memeriksa bahwa standar dan kualitas pendidikan yang lebih tinggi memenuhi harapan yang disepakati. Kualitas akademik adalah seberapa baik penyelenggara pendidikan tinggi mendukung dalam belajar dan pengajaran, dukungan yang tersedia, bagaimana menilai, dan sumber daya yang tersedia yang masih memenuhi ambang batas standar. Ambang batas standar akademik yaitu tingkat minimum prestasi yang akan dimiliki untuk mencapai sukses pada program studi dan mencapai kualifikasi. Fitur utama dari hal ini adalah bahwa ambang batas standar tidak boleh bervariasi dari penyelenggara satu perguruan tinggi dengan yang lainnya. 
Peningkatan kualitas mengambil langkah-langkah yang disengaja untuk membawa perbaikan tingkat efektivitas kurva belajar mahasiswa.

\section{Konsep Mutu dan Jaminan Mutu.}

Kualitas, sebagai sebuah konsep, telah didefinisikan secara berbeda oleh para pemangku kepentingan yang berbeda. Hal ini karena kualitas adalah multi-dimensi dan mempunyai arti yang berbeda bagi para pemangku kepentingan yang berbeda. Selain itu, negara-negara yang berbeda mungkin cenderung untuk mendefinisikan kualitas secara berbeda. Tulisan ini mengadopsi definisi kualitas, jaminan mutu, akreditasi, dan lisensi dari Materu (2007). Kualitas teknis mengacu pada kesesuaian untuk tujuan. Ini merangkum konsep memenuhi ajaran atau standar yang disepakati bersama. Standar tersebut dapat didefinisikan oleh hukum, lembaga, badan koordinasi atau masyarakat profesional. Dalam beragam lingkup pendidikan tinggi, kesesuaian untuk tujuan sangat bervariasi dengan bidang dan program tersebut.

Kualitas dalam konteks pendidikan tinggi mengacu pada - kesesuaian untuk tujuan atau sesuai dengan standar yang berlaku umum seperti yang didefinisikan oleh lembaga, badan jaminan kualitas dan komunitas akademik dan profesional yang sesuai, dimana dalam lingkup kesesuaian pendidikan tinggi untuk tujuan sangat bervariasi dengan bidang dan program. Faktor-faktor yang mempengaruhi kualitas di perguruan tinggi meliputi visi misi dan tujuan, bakat dan keahlian staf pengajar mereka masuk dalam penilaian standar, pengajaran, lingkungan belajar, kemampuan kerja lulusannya (mengacu pada pasar tenaga kerja), kualitas perpustakaan dan laboratorium, efektivitas manajemen, tata kelola dan kepemimpinan. (Marjorie, 2004).

Sejumlah faktor yang mempengaruhi kualitas di perguruan tinggi termasuk visi dan tujuan, bakat dan keahlian staf pengajar, penerimaan dan penilaian standar, pengajaran dan lingkungan belajar, kemampuan kerja lulusannya (relevansi dengan pasar tenaga kerja), kualitas perpustakaan dan laboratorium, efektivitas manajemen, tata kelola dan kepemimpinan. Jaminan kualitas adalah proses review terencana dan sistematis dari suatu lembaga atau program untuk menentukan apakah sudah atau tidak standar yang dapat diterima pendidikan, beasiswa, dan infrastruktur terpenuhi, dipelihara dan ditingkatkan. (Hayward 2001). Sebuah perguruan tinggi yang 
menyakini baik dalam kualitas pengajaran, staf-mereka adalah jantung dari lembaga yang menghasilkan lulusan, produk penelitian, dan pelayanan yang diberikan kepada lembaga, masyarakat, dan bangsa.

\section{Eksternal dan internal Quality Assurance}

Jaminan kualitas dapat berupa proses eksternal atau internal. Jaminan kualitas eksternal (EQA) mengacu pada tindakan badan eksternal, yang lembaga jaminan mungkin kualitas atau badan lain yang berbeda dari institusi, yang menilai operasi atau program dalam rangka untuk menentukan apakah itu memenuhi standar yang telah disetujui. Hal ini juga mengacu pada review oleh lembaga eksternal (misalnya lembaga jaminan kualitas nasional) atau badan (misalnya badan profesional), yang mengevaluasi operasi universitas (kelembagaan) atau program untuk mengetahui tingkat kepatuhan dengan menetapkan standar minimum. Jaminan kualitas eksternal terutama dilakukan melalui perantaraan akreditasi.

Penjaminan mutu internal, di sisi lain, mengacu pada kebijakan internal dan mekanisme universitas atau program untuk memastikan bahwa itu memenuhi tujuan serta standar yang berlaku untuk pendidikan tinggi secara umum atau profesi atau disiplin . Kualitas merupakan konsep multi-dimensi , dimana tidak ada definisi yang diterima secara umum tetapi umumnya mengukur tingkat realisasi menetapkan standar atau target. Kualitas telah menjadi faktor intrinsik penting dalam proses institusional, termasuk pendidikan tinggi . Konsep terkait jaminan kualitas juga menjadi penting secara global dalam diskusi pendidikan tinggi . Perhatian lebih dicurahkan hari ini untuk masalah penjaminan mutu pendidikan tinggi dari sebelumnya . Hal ini tidak mengherankan sebagai stakeholder dalam pendidikan tinggi sekarang menyadari pentingnya kualitas dan jaminan mutu dalam pendidikan tinggi . Stakeholders yang tertarik dalam jaminan kualitas meliputi:

a) siswa, b) orang tua, c) pemerintah, d) majikan, e) institusi itu sendiri,f) masyarakat

\section{Model PDCA( Plan, Do, Control, Action)}

Salah satu model kendali mutu yang digunakan adalah model PDCA( Plan, Do, Control, Action), yang menghasilkan perkembangan yang berkelanjutan (continuous 
improvement) atau kaizen mutu perguruan tinggi. Model PDCA ini dapat dilihat pada gambar berikut:

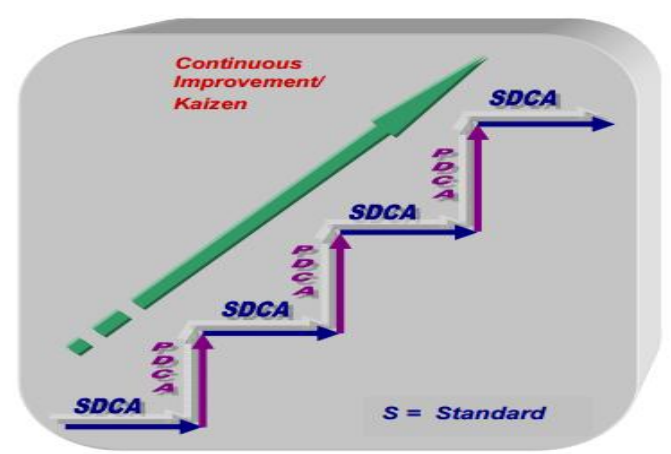

Gambar 2. Tahapan PDCA

Beberapa Prinsip manajemen kendali mutu berbasis PDCA adalah:

a. Quality first. Semua pikiran dan tindakan pengelola Perguruan Tinggi harus memprioritaskan mutu

b. Stakeholder-in. Semua pikiran dan tindakan pengelola Perguruan Tinggi harus ditujukan Pada kepuasan stakeholders

c. The next proses is our stakeholders. Setiap orang yang melaksanakan tugas dalam proses pendidikan tinggi, harus menganggap orang lain yang menggunakan hasil pelaksanaan tugasnya sebagai stakeholdernya yang harus dipuaskan.

d. Speak with data. Setiap orang pelaksana pendidikan tinggi harus melakukan tindakan dan mengambil keputusan berdasarkan analisis data yang telah diperolehnya terlebih dulu, bukan berdasarkan andaian atau rekayasa.

e. Upstream Management. Semua Pengambilan keputusan di dalam proses pendidikan tinggi dilakukan secara partisipatif, bukan otoritatif.

\section{METODE}

Penelitian ini adalah penelitian kualitatif pada studi kasus suatu prodi dari Perguruan Tinggi "XYZ", yang dilakukan dengan cara Focus Group Discussion (FGD). Yang termasuk dalam FGD adalah: Kaprodi atau Sekprodi, beberapa dosen, wakil dari fakultas, wakil dari universitas. Dalam melakukan FGD, dibahas per indikator instrumen EMI, kemudian mengevaluasi kondisi yang ada berdasarkan apa yang dimaksud dengan indikator. Dari evaluasi kondisi yang ada maka dibuatlah deskripsi 
dari kondisi tersebut. Selanjutnya dengan deskripsi yang dibuat, dilihat rubrik yang paling mendekati kondisi yang ada untuk menentukan skor yang dicapai untuk kondisi tersebut.

Di dalam EMI dilengkapi dengan target rencana untuk satu tahun ke depan, berdasarkan nilai skor yang diberikan. Dalam menetapkan target, maksimum adalah skor 7. Untuk menaikkan satu skor, perlu adanya analisis yang realistik yang mengacukan pada kemampuan dan prodi/ Perguruan Tinggi seperti beban kerja dosen, kemampuan keuangan, kemampuan personil dan banyaknya perencanaan yang masih berjalan atau belum terealisasi. Dalam kondisi tertentu dapat saja target untuk menaikkan skor tidak dilakukan atau tetap sama dengan skor yang diperoleh. Untuk melaksanakan target, perlu ditetapkan siapa pelaksananya dan berapa biaya untuk melaksanakan target tersebut. Ada kalanya dalam pelaksanaan mungkin juga tidak memerlukan biaya. Biaya dapat diestimasikan secara kasaran. Di dalam rangkuman skor berdasarkan pada rentang nilai seperti pada tabel-2, dibuat analisa Kekuatan, Kelemahan, Peluang dan Tantangan (analisa SWOT). Dari analisa tersebut dibuat rekomendasi implementasi pelaksanaan untuk peningkatan jangka pendek dan jangka panjang. Dengan demikian ada sebelas rekomendasi, selanjutnya di distribusikan pelaksanaannya kepada yayasan dan kepada pelaksana Perguruan Tinggi.. Pada bagian akhir akan ditampilkan juga skor masing-masing standar dalam bentuk grafik laba-laba.

Tabel 2. Rentang Angka Mutu dan sebutannya

\begin{tabular}{|c|c|l|}
\hline \multicolumn{4}{|c|}{ Konversi Angka Mutu ke Sebutan } \\
\hline Dari & Ke & Sebutan \\
\hline 0,00 & 14 & $\begin{array}{l}\text { Perbaikan menyeluruh dan } \\
\text { mendesak }\end{array}$ \\
\hline 15,00 & 28 & Perbaikan mayor \\
\hline 29,00 & 42 & Perbaikan minor \\
\hline 43,00 & 57 & Cukup \\
\hline 58,00 & 71 & Lebih dari Cukup \\
\hline 72,00 & 85 & Baik \\
\hline 86,00 & 100 & Sangat baik \\
\hline
\end{tabular}

\section{HASIL DAN PEMBAHASAN}

Berikut adalah hasil akhir dari Evalusi mutu internal suatu prodi dari Perguruan Tinggi "XYZ", yang berupa rekap skor yang diperoleh dan gambar grafik dari skor 
tersebut, analisis SWOT dan rekomendasinya, serta pembagian tugas kepada Yayasan dan pelaksana Perguruan Tinggi untuk jangka pendek dan jangka panjang. Nilai skor per standar dalam skala 0 s/d 100. Rekap dari nilai Mutu Prodi dapat dilihat pada tabel 3. Standar Isi mendapat nilai 85,71 dengan sebutan Baik. Standar yang memperoleh sebutan "lebih dari cukup" adalah: Standar Proses, Standar Kompetensi lulusan, Standar Pendidik dan Tenaga Kependidikan, Standar Sarana dan Prasarana, dan Standar Pengelolaan. Standar yang memperoleh sebutan "cukup" adalah : Standar Pembiayaan, Standar penilaian, dan Standar Pengabdian kepada Masyarakat. Standar Penelitian mendapat sebutan"Perbaikan Minor" sedangkan Standar Kerja sama memperoleh sebutan "Perbaikan Mayor". Secara nilai rata-rata standar memperoleh nilai 62,34 dengan sebutan "lebih dari cukup". Mengacu pada nilai rata-rata, ada 6 standar di atas nilai rata-rata dan ada 5 standar di bawah nilai rata-rata. Nilai yang terendah adalah Standar Kerjasama, sedangkan nilai yang tertinggi adalah standar Isi. Gambar 3 memperlihatan nilai skor standar dalam grafik laba-laba. Dari grafik sangat jelas terlihat mana saja standar yang di atas nilai ratarata dan mana saja standar yang di bawah nilai rata-rata. Dengan melihat pada grafik saja seorang pembuat keputusan sudah dapat melihat secara jelas kondisi mutu dari suatu prodi atau perguruan tinggi, sehingga sudah dapat dengan segera menentukan langkah apa yang diperlukan untuk memperbaiki mutu yang ada.

Tabel 3. Nilai Mutu Standar yang diperoleh

\begin{tabular}{|l|c|c|}
\hline \multicolumn{1}{|c|}{ Rekap nilai } & Nilai per standar & Sebutan \\
\hline A. Standar Isi & 85,71 & Baik \\
\hline B. Standar Proses & 71,43 & Lebih dari Cukup \\
\hline C Standar Kompetensi Lulusan & 71,43 & Lebih dari Cukup \\
\hline D Standar Pendidik dan Tenaga Kependidikan & 71,43 & Lebih dari Cukup \\
\hline E Standar Sarana dan Prasarana & 71,43 & Lebih dari Cukup \\
\hline F Standar Pengelolaan & 71,43 & Lebih dari Cukup \\
\hline G Standar Pembiayaan & 57,14 & Cukup \\
\hline H Standar Penilaian & 57,14 & Cukup \\
\hline I Standar Penelitian & 42,86 & Perbaikan minor \\
\hline
\end{tabular}




\begin{tabular}{|l|c|c|}
\hline J Standar Pengabdian kepada Masyarakat & 57,14 & Cukup \\
\hline K Standar Kerjasama & 28,57 & Perbaikan mayor \\
\hline Rata-rata & $\mathbf{6 2 , 3 4}$ & Lebih dari Cukup \\
\hline
\end{tabular}

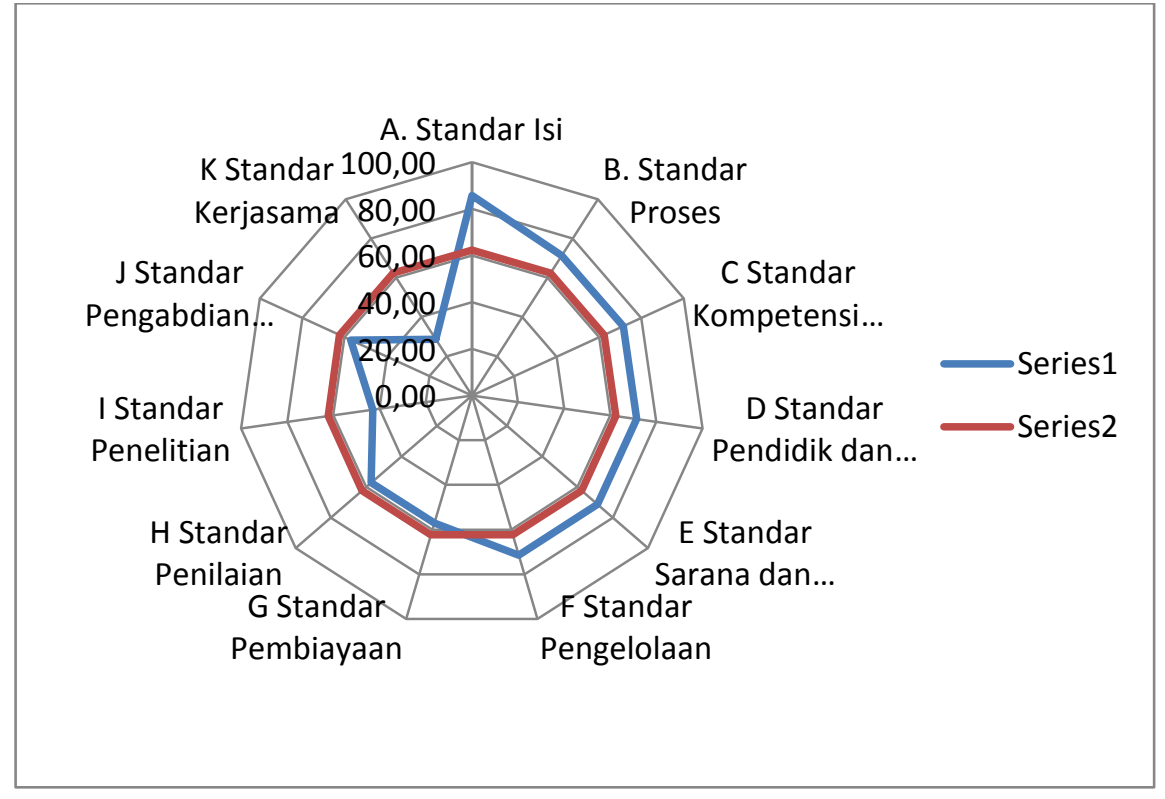

Gambar 3. Grafik Laba-laba Skor dari Standar

Berdasarkan pada pengisian nilai skor dan target dan analisis kondisi yang aktual, maka dibuat analisis SWOT seperti pada tabel 4. Berdasarkan analisis SWOT ini maka dapatlah dibuat rekomendasi untuk jangka pendek maupun jangka panjang seperti pada tabel-5 dan rekomendasi khusus seperti pada tabel-6.

Tabel 4. Analisis keunggulan, kelemahan/keterbatasan tantangan, peluang

\begin{tabular}{|l|c|c|c|c|}
\hline \multicolumn{1}{|c|}{ Standar } & \multicolumn{1}{|c|}{ Keunggulan } & $\begin{array}{c}\text { Kelemahan/ } \\
\text { Keterbatasan }\end{array}$ & Tantangan & Peluang \\
\hline $\begin{array}{l}\text { A. Standar } \\
\text { Isi }\end{array}$ & $\begin{array}{c}\text { Kurikulum selalu } \\
\text { berkembang sesuai } \\
\text { dengan kebutuhan } \\
\text { masyarakat }\end{array}$ & $\begin{array}{c}\text { Monitoring dan } \\
\text { evaluasi } \\
\text { implementasi } \\
\text { kurikulum hanya } \\
\text { dilakukan secara } \\
\text { insidental }\end{array}$ & $\begin{array}{c}\text { Membuat kurikulum } \\
\text { yang sesuai dengan } \\
\text { kebutuhan } \\
\text { masyarakat }\end{array}$ & $\begin{array}{c}\text { Kesadaran masyarakat } \\
\text { untuk mendapatkan } \\
\text { kompetensi secara formal }\end{array}$ \\
\hline $\begin{array}{l}\text { B. Standar } \\
\text { Proses }\end{array}$ & $\begin{array}{c}\text { Dukungan dan } \\
\text { semangat dari } \\
\text { sivitas akademika } \\
\text { untuk meningkatkan } \\
\text { proses pembelajaran }\end{array}$ & $\begin{array}{c}\text { Kurangnya iklim } \\
\text { monitoring dan } \\
\text { evaluasi }\end{array}$ & $\begin{array}{c}\text { Membangun } \\
\text { suasana akademik } \\
\text { yang kondusif jika } \\
\text { tidak akan kalah } \\
\text { bersaing dengan } \\
\text { perguruan tinggi } \\
\text { lain }\end{array}$ & $\begin{array}{c}\text { Mengoptimalkan dalam } \\
\text { membangun suasana } \\
\text { akademik yang kondusif }\end{array}$ \\
\hline $\begin{array}{l}\text { C Standar } \\
\text { Kompetensi } \\
\text { Lulusan }\end{array}$ & $\begin{array}{c}\text { Mempunyai daya } \\
\text { juang mahasiswa } \\
\text { yang tinggi }\end{array}$ & $\begin{array}{c}\text { Kemampuan } \\
\text { mahasiswa yang } \\
\text { terbatas }\end{array}$ & $\begin{array}{c}\text { Meningkatkan } \\
\text { kualitas SDM }\end{array}$ & $\begin{array}{c}\text { Adanya kekeluargaan } \\
\text { yang baik dengan alumni }\end{array}$ \\
\hline
\end{tabular}




\begin{tabular}{|c|c|c|c|c|}
\hline $\begin{array}{l}\text { D Standar } \\
\text { Pendidik } \\
\text { dan Tenaga } \\
\text { Kependidik } \\
\text { an }\end{array}$ & $\begin{array}{l}\text { Kualifikasi dosen } \\
\text { sudah cukup } \\
\text { memenuhi }\end{array}$ & $\begin{array}{c}\text { Belum ada pedoman } \\
\text { yang jelas } \\
\text { pengembangan } \\
\text { karir, remunerasi } \\
\text { dan pemberian } \\
\text { penghargaan dan } \\
\text { sangsi } \\
\end{array}$ & $\begin{array}{l}\text { Meningkatkan studi } \\
\text { lanjut, memperbaiki } \\
\text { pedoman } \\
\text { kepegawaian dan } \\
\text { melaksanakan } \\
\text { secara konsisten }\end{array}$ & $\begin{array}{l}\text { Memperbanyak even- } \\
\text { even diluar eksternal yang } \\
\text { dapat diikuti supaya dapat } \\
\text { meningkatkan kompensi }\end{array}$ \\
\hline $\begin{array}{l}\text { E Standar } \\
\text { Sarana dan } \\
\text { Prasarana }\end{array}$ & $\begin{array}{l}\text { Ruang perpustakaan } \\
\text { yang cukup luas } \\
\text { adanya jaringan } \\
\text { internet }\end{array}$ & $\begin{array}{l}\text { Terbitan buku-buku } \\
\text { yang sudah lama, } \\
\text { belum siapnya e- } \\
\text { library, minimnya } \\
\text { jurnal-jurnal, ruang } \\
\text { praktikum yang } \\
\text { belum lengkap }\end{array}$ & $\begin{array}{l}\text { Sudah semakin } \\
\text { diperlukan sarana } \\
\text { prasarana yang } \\
\text { memadai }\end{array}$ & $\begin{array}{c}\text { Dimungkinkannya untuk } \\
\text { mengadakan buku serta } \\
\text { membangun lab. }\end{array}$ \\
\hline $\begin{array}{l}\text { F Standar } \\
\text { Pengelolaan }\end{array}$ & $\begin{array}{l}\text { Adanya pedoman } \\
\text { pengelolaan }\end{array}$ & $\begin{array}{l}\text { Keterbatasan jumlah } \\
\text { pendaftar sebagai } \\
\text { calon mahasiswa }\end{array}$ & $\begin{array}{l}\text { Adanya perguruan } \\
\text { tinggi di hampir } \\
\text { setiap kabupaten }\end{array}$ & $\begin{array}{c}\text { Mempunyai nama besar } \\
\text { dari pendiri perguruan } \\
\text { tinggi }\end{array}$ \\
\hline $\begin{array}{l}\text { G Standar } \\
\text { Pembiayaan }\end{array}$ & $\begin{array}{c}\text { Sudah dimiliki } \\
\text { dokumen kebijakan } \\
\text { pengelolaan } \\
\text { anggaran }\end{array}$ & $\begin{array}{c}\text { Anggaran masih } \\
\text { terpusat pada } \\
\text { universitas dan } \\
\text { fakultas serta } \\
\text { sumberdana } \\
\text { sebagian besar dari } \\
\text { mahasiswa }\end{array}$ & $\begin{array}{c}\text { Mengupayakan } \\
\text { sumberdana selain } \\
\text { dari mahasiswa }\end{array}$ & $\begin{array}{c}\text { Adanya penawaran hibah, } \\
\text { memperluas jaringan } \\
\text { kerjasama }\end{array}$ \\
\hline $\begin{array}{l}\text { H Standar } \\
\text { Penilaian }\end{array}$ & $\begin{array}{l}\text { Adanya pedoman } \\
\text { penilaian ujian } \\
\text { UTS, UAS dan } \\
\text { ujian tugas akhir }\end{array}$ & $\begin{array}{l}\text { Sistem penilaian } \\
\text { belum melibatkan } \\
\text { stake holder }\end{array}$ & $\begin{array}{c}\text { Membuat pedoman } \\
\text { penilaian dengan } \\
\text { melibatkan stake } \\
\text { holder }\end{array}$ & $\begin{array}{l}\text { Memperbaiki pedoman } \\
\text { penilaian }\end{array}$ \\
\hline $\begin{array}{l}\text { I Standar } \\
\text { Penelitian }\end{array}$ & $\begin{array}{c}\text { Sudah dimiliki } \\
\text { pedoman pnelitian }\end{array}$ & $\begin{array}{c}\text { Anggaran yang } \\
\text { terbatas untuk } \\
\text { penelitian } \\
\text { pembuatan modul } \\
\text { kuliah serta untuk } \\
\text { pengiriman dosen } \\
\text { sebagai penyaji } \\
\text { dalam seminar } \\
\text { ilmaih } \\
\end{array}$ & $\begin{array}{l}\text { Universitas melalui } \\
\text { lembaga penelitian } \\
\text { harus selalu } \\
\text { menginformasikan } \\
\text { adanya penawaran } \\
\text { hibah penelitian }\end{array}$ & $\begin{array}{c}\text { Banyaknya penawaran } \\
\text { hibah penelitian }\end{array}$ \\
\hline $\begin{array}{l}\text { J Standar } \\
\text { Pengabdian } \\
\text { kepada } \\
\text { Masyarakat }\end{array}$ & $\begin{array}{c}\text { Sudah dimiliki } \\
\text { pedoman } \\
\text { pengabdian kepada } \\
\text { masyarakat }\end{array}$ & $\begin{array}{c}\text { Anggaran } \\
\text { pengabdian } \\
\text { masyarakat yang } \\
\text { sangat terbatas, } \\
\text { belum terintegrasi } \\
\text { antara penelitian } \\
\text { dengan pengabdian } \\
\text { masyarakat } \\
\end{array}$ & $\begin{array}{c}\text { Mencari tempat } \\
\text { pengabdian kepada } \\
\text { masyarakat }\end{array}$ & $\begin{array}{c}\text { Banyaknya penawaran } \\
\text { hibah pengabdian kepada } \\
\text { masyarakat }\end{array}$ \\
\hline $\begin{array}{l}\text { K Standar } \\
\text { Kerjasama }\end{array}$ & $\begin{array}{c}\text { Terdapat kerjasama } \\
\text { baik tingkat fakultas } \\
\text { maupun universitas }\end{array}$ & $\begin{array}{l}\text { Belum ada pedoman } \\
\text { yang jelas dalam } \\
\text { kerjasama }\end{array}$ & $\begin{array}{c}\text { Meningkatkan } \\
\text { kerjasama }\end{array}$ & $\begin{array}{c}\text { Ada penawaran dari } \\
\text { perguran tinggi lain untuk } \\
\text { kerjasama }\end{array}$ \\
\hline
\end{tabular}

Tabel 5. Rekomendasi.

\begin{tabular}{|l|l|}
\hline \multicolumn{1}{|c|}{ Standar } & \multicolumn{1}{c|}{ Rekomendasi } \\
\hline A. Standar Isi & Prodi harus lebih intensif dan kreatif dalam pengembangan kurikulum \\
\hline B. Standar Proses & Membangun suasana akademik yang kondusif \\
\hline $\begin{array}{l}\text { C Standar Kompetensi } \\
\text { Lulusan }\end{array}$ & Meningkatkan dan mengefektifkan pertemuan dengan alumni \\
\hline
\end{tabular}




\begin{tabular}{|l|l|}
\hline $\begin{array}{l}\text { D Standar Pendidik dan } \\
\text { Tenaga Kependidikan }\end{array}$ & $\begin{array}{l}\text { PT memberi dukung sarana dan prasarana serta menetapkan pedoman, } \\
\text { memberikan dukungan untuk studi lanjut }\end{array}$ \\
\hline $\begin{array}{l}\text { E Standar Sarana dan } \\
\text { Prasarana }\end{array}$ & $\begin{array}{l}\text { Meningkatkan e-library, mengadakan buku, membuat lab. Perbankan dan } \\
\text { lab, corporate untuk pembelajaran }\end{array}$ \\
\hline F Standar Pengelolaan & Mengintensifkan promosi dan sekaligus melakukan bimbingan karir \\
\hline G Standar Pembiayaan & Prodi diberi keluasaan mengelola anggaran serta mendirikan unit bisnis \\
\hline H Standar Penilaian & Menyusun pedoman penilaian \\
\hline I Standar Penelitian & $\begin{array}{l}\text { Penambahan anggaran untuk penelitian, pembuatan buku/modul, } \\
\text { pengiriman pada call paper }\end{array}$ \\
\hline $\begin{array}{l}\text { J Standar Pengabdian } \\
\text { kepada Masyarakat }\end{array}$ & Perlunya menambah anggaran pengabdian kepada masyarakat \\
\hline K Standar Kerjasama & Melakukan kegiatan kerjasama dalam Tri Dharma \\
\hline
\end{tabular}

Temuan hasil Evaluasi Mutu Internal menunjukkan bahwa di dalam pelaksanaan program studi masih terdapat beberapa kekurangan yaitu pada standar pembiayaan, standar penelitian dan standar pengabdian kepada masyarakat dan Standar Kerjasama. Untuk selanjutnya, hasil dari EMI ini dapat digunakan sebagai acuan untuk perencanaan pengembangan mutu pendidikan dari program studi untuk satu tahun ke depan guna menuju pada tingkat akreditasi yang direncanakan.

Tabel 6. Rekomendasi khusus

\begin{tabular}{|l|l|ll|}
\hline $\begin{array}{l}\text { Rekomendasi } \\
\text { Khusus }\end{array}$ & \multicolumn{1}{|c|}{ Jangka Pendek } & \multicolumn{3}{c|}{ Jangka Panjang } \\
\hline $\begin{array}{l}\text { Perguruan } \\
\text { Tinggi }\end{array}$ & $\begin{array}{l}\text { Tersedia : anggaran yang memadai, } \\
\text { memudahkan mengakses e-library, } \\
\text { membuat Lab membuat pedoman- } \\
\text { pedoman, menyediakan daya dukung } \\
\text { yang memadai untuk kegiatan ilmiah baik } \\
\text { nasional maupun internasional }\end{array}$ & $\begin{array}{l}\text { Studi lanjut dosen dan tenaga } \\
\text { kependidikan, }\end{array}$ & \\
\hline $\begin{array}{l}\text { Yayasan/Wali } \\
\text { Amanah/Bad } \\
\text { an wakaf }\end{array}$ & Memberi dukungan pada semua kegiatan & $\begin{array}{l}\text { Memberikan anggaran untuk sarana } \\
\text { prasarana. } \\
\text { Meningkatkan dan menggali sumber } \\
\text { dana, mendirikan unit bisnis }\end{array}$ \\
\hline
\end{tabular}

Rekomendasi dari hasil analisa SWOT dan rekomendasi khusus menjadi program kerja prodi, perguruan tinggi dan Yayasan, apakah itu program kerja jangka pendek dan jangka panjang. Hasil EMI ini selanjutnya ditahun berikutnya dilakukan evalusi apakah program-prograam telah dilaksanakan seluruhnya atau masih berjalan. Dengan adanyanya EMI dilaksanakan setiap tahun, maka prodi/ perguruan tinggi akan terus meningkat kualitasnya, dan budaya mutu menjadi berkembang dan pada akhirnya akan dapat bersaing di dunia global. 


\section{KESIMPULAN DAN SARAN}

\section{Kesimpulan :}

Dengan implementasi EMI pada prodi maka dapat disimpulkan:

1. Standar Pembiayaan perlu ditingkatkan penganggaran dananya

2. Standar Penelitian, dan Standar Pengabdian Masyarakat perlu ditingkatkan motivasi dosen dan perlu adanya peningkatan pendanaan untuk kegiatan tersebut.

3. Standar Kerjasama, perguruan tinggi harus lebih meningkatkan kerja samanya dengan berbagai pihak.

4. Dengan mengimplementasikan EMI secara teratur, diharapkan kualitas pendidikan akan terus meningkat sehingga dapat bersaing secara global.

\section{Saran:}

1. EMI sebaiknya dapat di budayakan pada setiap Perguruan Tinggi

\section{DAFTAR PUSTAKA}

Direktorat Jenderal Pendidikan Tinggi Departemen Pendidikan Nasional, 2006, Panduan Pelaksanaan Sistem Penjaminan Mutu Perguruan Tinggi (SPMPT)Bidang Akademik.

Fadokun James, 2000, External Quality Assurance in Higher Education: The Need for a paradigm shift, Banji Research and Training Fellow, National Institute for Educational Planning and Administration,Ondo, Ondo State.Nigeria

Hayward, F.M.(2001)Glossary of Quality Assurance Terms .Council or Higher Education Accreditation

Kementerian Pendidikan dan Kebudayaan, 2012, Evaluasi Mutu Internal Perguruan Tinggi Indonesia, Badan Pengembangan Sumber Daya Manusia Pendidikan dan Kebudayaan dan Penjaminan Mutu Pendidikan Pusat Penjaminan Mutu Pendidikan, Bidang Pendidikan Menengah dan Pendidikan Tinggi

Marjorie,P.L.(2002) Quality Assurance and Accreditation in Higher Education

Materu,P.(2007) Higher Education Quality Assurance in Sub -Saharan Africa:Status,Challenges, Opportunities, and Promising Practices Washington 